\title{
Alternatives to Medical Treatment by Physicians
}

In today's Western industrial countries, academically educated physicians for the most part have a monopoly on healthcare. This is a relatively recent historical development. Despite their growing numbers, learned physicians until well into the nineteenth century represented only a small minority of healthcare providers. Throughout the entire early modern period, they existed alongside a great variety of other healers. Competing with them in the health market were barbers and barber-surgeons who were trained as craftsmen as well as lay healers of all stripes. ${ }^{514}$ Not only this, but everyone in contemporary society had a certain basic medical knowledge at their disposal and could treat themselves with home remedies. In other words, when people fell ill, they had the choice between a range of alternative options - and quite frequently they would resort to more than one, in the course of time.

\section{Self-Treatment and Domestic Medicine}

In the sixteenth century, having a sound knowledge of the genesis and treatment of diseases was not the prerogative of professional healers. As is also shown by countless entries in Handsch's notebooks, basic medical knowledge was widespread in the population. For an educated minority, it was possible to turn to medical manuals and health guides written in the vernacular. ${ }^{515}$ Some of the authors and editors of such works were severely rebuked for passing medical knowledge on to the uninitiated. ${ }^{516}$ But the most crucial medium for the dissemination of medical knowledge among the lay population was - and this went for all social classes - the spoken word. ${ }^{517}$ People discussed medical matters. They shared their positive experiences with certain medicines and treatment procedures. And they applied this knowledge when they themselves or their relatives or neighbors got sick.

514 An important seminal study on the early modern healthcare market is Park, Doctors (1985); for a more recent overview, see Wallis, Medicine (2007) and for a case study on Cologne, see Jütte, Medical pluralism (2013), pp. 32-37.

515 E.g. Gasser, Bericht (1544); Glaubitz, Zwo Haußtaffeln (1584); Starck, Krancken Spiegel (1598); Wittich, Praeservator sanitatis (1590).

516 Telle, Arzneikunst (1982), pp. 43-48.

517 Lindemann, Medicine and society (2010), pp. 121-122 has likewise concluded that "the most frequent sites of medical education (broadly understood) were families, households, and neighborhoods".

Ә Open Access. (c) 2022 Michael Stolberg, published by De Gruyter. (c) BY-NC-ND This work is licensed under the Creative Commons Attribution-NonCommercial-NoDerivatives 4.0 International License. https://doi.org/10.1515/9783110733549-020 
Time and again, Handsch noted down what laypeople had told him about their successful self-treatment. A goldsmith, for example, told him that a decoction of horse hair had alleviated the ulcer in his urethra after he had tried in vain to treat it with sulfuric acid. ${ }^{518}$ Caspar Belwitz recovered from a paralyzed limb the same night that some women had given him lavender water to drink and had rubbed the affected limb with myrrh and mustard. ${ }^{519}$ By his own account, a lapidary healed his mother's gangrene with alum, frankincense, and myrrh - and this while the surgeons were beginning to speak of amputation. ${ }^{520}$

Various domestic remedies were known in Handsch's own family and put to use when necessary. Handsch's stepmother explained to him that iris helped with infant stomachaches. ${ }^{521}$ It was also his stepmother to whom he owed a remedy that could be given to children when they, like one of his nieces, rolled their eyes during seizures; it appears there was a concern that the child might become permanently cross-eyed. One had to chew caraway seeds and then breathe into the face of the child, who then would be able to see straight again. ${ }^{522}$ One of the remedies Handsch's sister Apollonia praised was using linen dipped in salt water to cure headaches. ${ }^{523}$ She also advised applying hare brain to the sore gums of teething children. ${ }^{524}$ Handsch noted that his father ate roasted figs when he was developing a cough, and it helped. ${ }^{525}$ During a fever epidemic, he drank sorrel water to fend off febrile attacks and tied creeping cinquefoil to the soles of his feet. Handsch's father explained that Georg's stepmother had done this as well when she had been ill with tertian fever, and he advised the local town clerk to do the same. ${ }^{526}$

Even those in the highest circles of society - people who could easily afford the help of a physician - were keen to acquire medical knowledge and sometimes engaged in healing practices of their own. As Alicia Rankin has demonstrated for Anna von Sachsen, Dorothea von Mansfeld, Elisabeth von Rochlitz, some noblewomen were particularly interested in delving into medical questions and producing medicines. ${ }^{527}$ In Ambras Castle, Ferdinand's mother-in-law

518 Cod. 11183, fol. 188r.

519 Ibid., fol. 206r.

520 Ibid., fol. $2 \mathrm{v}$.

521 Cod. 11205, fol. 122r.

522 Cod. 11183, fol. 207v.

523 Ibid., fol. 10v; Cod. 11251, fol. 39r.

524 Cod. 11183, fol. 240v.

525 Ibid.

526 Cod. 11207, fol. 210v; Cod. 11205, fol. 144r; usually Handsch simply referred to his "mother" ("mater") but his biological mother died in 1539 already.

527 Rankin, Panaceia’s daughters (2013). 
Anna Welser engaged in medical activities on a considerable scale. According to Handsch, she quite literally "prescribed" her domestic remedies to those who fell ill at the court and in the surrounding area. ${ }^{528}$ One of her favorite medicines was a so-called "Stechwasser" made from unknown ingredients. She gave this, along with rob sambucinum, made from elderberries, to a sick lady at the court, as well as to a sick woman in nearby Weierburg. ${ }^{529}$ In other cases she lent support by offering her medical advice and, at times, asserted herself over others. When a certain Eustachius was suffering from convulsions in his arms and legs, those caring for him wanted to hold him down and stop his movements. Anna Welser, however, would not allow it, saying that this could lead to paralysis. ${ }^{530}$

Anna Welser's daughter Philippine, the wife of the Archduke, also engaged in the healing arts. She often told Handsch about various remedies used routinely by the women in her hometown of Augsburg. ${ }^{531}$ Still today, she is known for her book of medicines filled with recipes she collected from various sources. ${ }^{532}$ She is said to have set up her own apothecary's shop at Ambras and to have produced various medicines with the apothecary. ${ }^{533}$ For her ailing husband she had remedies made from valuable gemstones, pearls, corals, and unicorn horn. ${ }^{534}$ She treated the wife of a chancellor with her "quintessence" and had a blistering plaster applied. ${ }^{535}$ Like her mother, she did not limit herself to treating relatives at the court. Handsch noted down, for example, the various remedies she used to treat the cancerous ulcer of a barber. Initially, a horrid odor was released, but then the ulcer healed. Unfortunately, the man then developed dropsy and died. ${ }^{536}$ Philippine also sent oil of absinth to a poor and sick man who was suffering from dropsy, leg ulcers, and worms. ${ }^{537}$

528 E.g. Cod. 11183, fol. 371r: "Vetula Welserin ordinavit ei Stechwasser".

529 Ibid., fol. 383v; Anna Welser asked for the same remedy in her own disease (ibid., fol. $362 \mathrm{r})$.

530 Ibid., fol. 326r.

531 Ibid., fol. 398r.

532 Hirn, Ferdinand II. (1885), p. 484; Hirn, Ferdinand II. (1887), p. 327; Beer, Philippine Welser (1950); Größing, Kaufmannstochter (1992); Größing, Heilkunst (1998).

533 Hirn, Ferdinand II. (1887), p. 327.

534 Cod. 11183, fol. 444r.

535 Ibid., fol. 481v.

536 Ibid., fol. 461v; Handsch did not question the efficacy of the medicines. His only reservation was that the man should have been purged before. Presumably, he felt it was necessary to first free the body of the morbid matter in this way which could no longer be evacuated through the ulcer. In his eyes, this was the reason why the patient ultimately became dropsical and died.

537 Ibid., fol. 366v. 
According to a cherished narrative, it was women first and foremost - the mothers of the household - who were formerly responsible for caring for the health of their families, using home remedies to treat their illnesses. This notion accords well with an image of female nature that continues to hold sway today: this is the perception of women as more attentive, caring, and empathetic than men, willing and able to devote themselves to the physical needs of their fellow human beings. Handsch's numerous entries on the medical knowledge of men which they put to use not least of all in their treatment of relatives - call on us to exercise a certain degree of caution. There are not enough sources for the population at large that would allow for more precise conclusions to be drawn about the extent to which men and women respectively engaged in the healing arts within their families and neighborhoods. It is very obvious, however, that involvement in matters of health, including the treatment of relatives, was by no means essentially limited to women. Men, too, could play a very active role. This is shown, for one thing, by the collections of tried and tested household recipes used in selftreatment, which were compiled not only by women but also - and perhaps even primarily - by men. ${ }^{538}$ Handsch's entries contain, for example, multiple references to the recipes and experiences a certain lapidary recorded in his recipe book. ${ }^{539}$

In cases where relatives asked for medical advice from a physician by letter, the active participation of men is especially evident. One father, for example, was worried about his son, who at the age of a year and a half was suffering from diarrhea in the middle of summer; Handsch copied excerpts from his letters. It had been going on for five days, wrote the father. This morning alone, the son had produced four very slimy, loose stools that had some blood mixed in as well. He went on to say that the boy had become very weak, his body hot. He was being breastfed by a wet nurse. Otherwise, he was not eating. ${ }^{540}$ Two days later, he reported that the child was still hot and feverish, but was otherwise feeling better. His stool was becoming firmer and its color was beginning to look more natural. He therefore considered it time to do something about the diarrhea itself - evidently, he had so far considered it an expression of nature's efforts to rid the body of morbid matter. He enclosed the recipe for a plaster which he had received from his brother's wife. However, he wrote that until he heard from Handsch, he planned to use only

538 In her analysis of early modern English recipe-books, Elaine Leong has come to a similar conclusion. According to Leong, these compilations cannot be attributed primarily to the women in the household but were the product of a shared activity in which men and women participated; cf. Leong, Collecting Knowledge (2013); Leong, Recipes (2018).

539 Cod. 11183, fol. $45 \mathrm{v}$ and fol. 154v, "in libro gemmicidae scriptum erat”; ibid., fol. 155 "oleum Antimonii ex libro gemmicidae".

540 Ibid., fol. 271v-272r. 
domestic remedies ("vulgaria remedia"). He had given the toddler a broth made with wheat beer and egg white, and the wet nurse, too, was given constipating food. And, following the advice of a certain Herr Schonfeld, who had used this remedy on his own son, he injected a warm infusion of mullein (verbascum) into the boy's anus. He added, however, that just as he was about to seal the letter, he saw that the feces were indeed still green, as Handsch could see from the enclosed linen cloths with greenish stool residue on them. This meant that it was unadvisable to limit defecation just yet. But he was asking for a recipe to counter the intense heat and the powerful urge to defecate. ${ }^{541}$ Two days after this letter was written, Handsch went to the village, saw the little boy, and prescribed him, among other things, embrocations to be applied to the abdomen. ${ }^{542}$ On the tenth day of illness, the child was feeling significantly better according to the father's account. He was playing again and no longer had such intense, foul diarrhea. But the father did ask for an invigorating remedy and compresses to strengthen the heart. He had seen how, in Germany, physicians often gave a socalled "Kraftwasser" - a drink that gave strength - in such cases. He furthermore asked for a remedy that would make the stool firmer and would take away the stomach pain and the heat. Of course, one had to take care not to treat the diarrhea too aggressively as the little boy was very susceptible to worms and one did not want to block their passage out of the body. ${ }^{543}$ In response to these wishes, Handsch sent him Neefe's "strengthening water" and a cardiac fomentation (epitema cordiale). Three days later, the father reported that the boy's condition had, overall, improved even more. Yet when he wanted to sleep, he was constantly awoken by pain, and kept reaching for his anus while screaming. The father had had a look at the boy's anus and had seen that the skin truly was irritated, likely from the ongoing discharge of acrid matter. Clearly the boy also experienced pain during defecation, and his private parts were swollen. The father asked Handsch to get him an enema as quickly as possible to cleanse the bowels. ${ }^{544}$ The following day, Handsch sent an apothecary to give the enema. But the apothecary was unsuccessful. All the liquid flowed back out immediately. Now, the father was furious with Handsch and the apothecary. He did not even try to apply the other remedies - an oil and a sage infusion - and instead sent for another physician. Two days later, Handsch learned that the child had died. ${ }^{545}$

541 Ibid., fol. 272r-272v, August 17.

542 Ibid., fol. 273 r.

543 Ibid., August 20.

544 Ibid., fol. 274r, August 21.

545 Ibid., fol. 274 r. 
We find indications of a thoroughgoing interest in matters of health and home remedies on the part of men even in the highest social circles. For example, an extensive collection of medical recipes, extant in Gotha, is connected with the name of Johann of Saxony. ${ }^{546}$ One of my own ancestors, Count Wolfgang Ernst zu Stolberg (1546-1606), also compiled such a book of recipes whose cover is magnificently adorned with his initials. ${ }^{547}$ Handsch for his part noted down a large number of the insights and experiences conveyed to him by men from the court or from the nobility. Count von Helfenstein, for example, explained to him that the slimy matter on the surface of frog ponds worked well for podagra. He said it needed to be heated up and applied to the painful area with a piece of cloth. ${ }^{548}$ And Handsch heard about the effects of a whole host of medicines and medical procedures from the captain of the castle of Brandeis, a position that was generally reserved for members of the nobility. In the case of fever, the patient was to walk over absinth plants, while with dysentery, a powder made with dried deer penis was beneficial. ${ }^{549}$ When his burgrave ("count of the castle") became ill with fever, the captain gave him powdered unicorn horn, about which he said "it is as valuable as its weight in gold". ${ }^{550}$ The captain even gave advice about obstetric matters. He had learned from his mother that the placenta would come out immediately if one held camphor to the woman's nose after she had delivered. ${ }^{551}$

Bearing in mind contemporary role patterns and gender norms, it is ultimately not surprising that men were interested and involved in medical matters and that they also treated their families. Men naturally had a concrete interest in treating their own illnesses if need be, but it went beyond this. As the heads of the family, they held the authority over the household. Furthermore, as opposed to women, men were significantly more likely to be able to read and write at the time - and hence to have access to health guidebooks and collections of recipes. It can be assumed, on the other hand, that it was predominantly women who prepared the medicines in their kitchens at home and that it was mainly they who nursed the sick.

546 Forschungsbibliothek Gotha, Memb. I, 111-113 (1515).

547 Privately owned.

548 Cod. 11251, fol. 157v; the entry probably refers to Georg von Helfenstein who worked as a teacher at court (magister curiae).

549 Cod. 11205, fol. $144 \mathrm{r}$ and fol. 148r.

550 Ibid., fol. 147r.

551 Ibid., fol. 150v. 


\section{Barbers and Barber-Surgeons}

When patients did not want to rely on home remedies alone, and decided to seek the help of a professional healer, barbers and barber-surgeons were an important alternative to learned physicians in many places. In the Holy Roman Empire, barbers and barber-surgeons were usually organized in guilds and received a master craftsman's certificate following their training and apprenticeship, which allowed them to establish and conduct their own workshop. Their domain was not only grooming and body care, but they were also active, on a regular basis and often above all, as medical practitioners. ${ }^{552}$

The Bader, translated here as "bath-master", was the keeper of a bathhouse; the Latin designation was balneator, balneatrix. Since operating a bathhouse required a stove and a plentiful water supply the bath-masters were bound to their location. On certain days, the bathhouse would be heated, with a masonry stove or with large stones that had been laid in embers to heat. What was important in any case was that the stove could be stoked from the outside so as not to fill the bathhouse with smoke. ${ }^{553}$ Hot stones could also be used to heat the water in the tubs. ${ }^{554}$ In some places, a horn was blown or a metal basin was loudly beaten to signal that the stove, the room, and the water were hot. ${ }^{555}$ In the better bathhouses, customers or patients entered a change room where they could lay their clothes. Women could cover their nakedness with a skirt or apron-like garment called a "Badehre" (lit. "bath honor"), while men were offered a decidedly short pair of trousers that barely concealed their private parts. Both sexes could also don a special bathing hat woven from straw. ${ }^{556}$

Customers could then take a warm bath in a wooden washtub. Often, herbs were added to the water, or a herbal decoction was used instead of pure water. ${ }^{557}$ Bath servants and maids were sometimes on hand to pour water over the bathing clientele and to "rub" or "scratch" their skin. Bundles of oak or birch twigs, tied to

552 On the history of barber-surgeons and bath-masters and their medical activities see Flamm, Bader (1996), Wehrli, Bader (1927) and the exhibition catalogue by Widmann/Mörgeli, Bader (1998), with numerous illustrations.

553 Widmann/Mörgeli, Bader (1998), p. 61.

554 Cod. 11183, fol. 253v.

555 Wehrli, Bader (1927), p. 10; Widmann/Mörgeli, Bader (1998), p. 50.

556 Wehrli, Bader (1927), p. 10; Flamm, Bader (1996), p. 17; Widmann/Mörgeli, Bader (1998), pp. 52f. and pp. 58f., with illustrations.

557 Wehrli, Bader (1927), p. 20. 


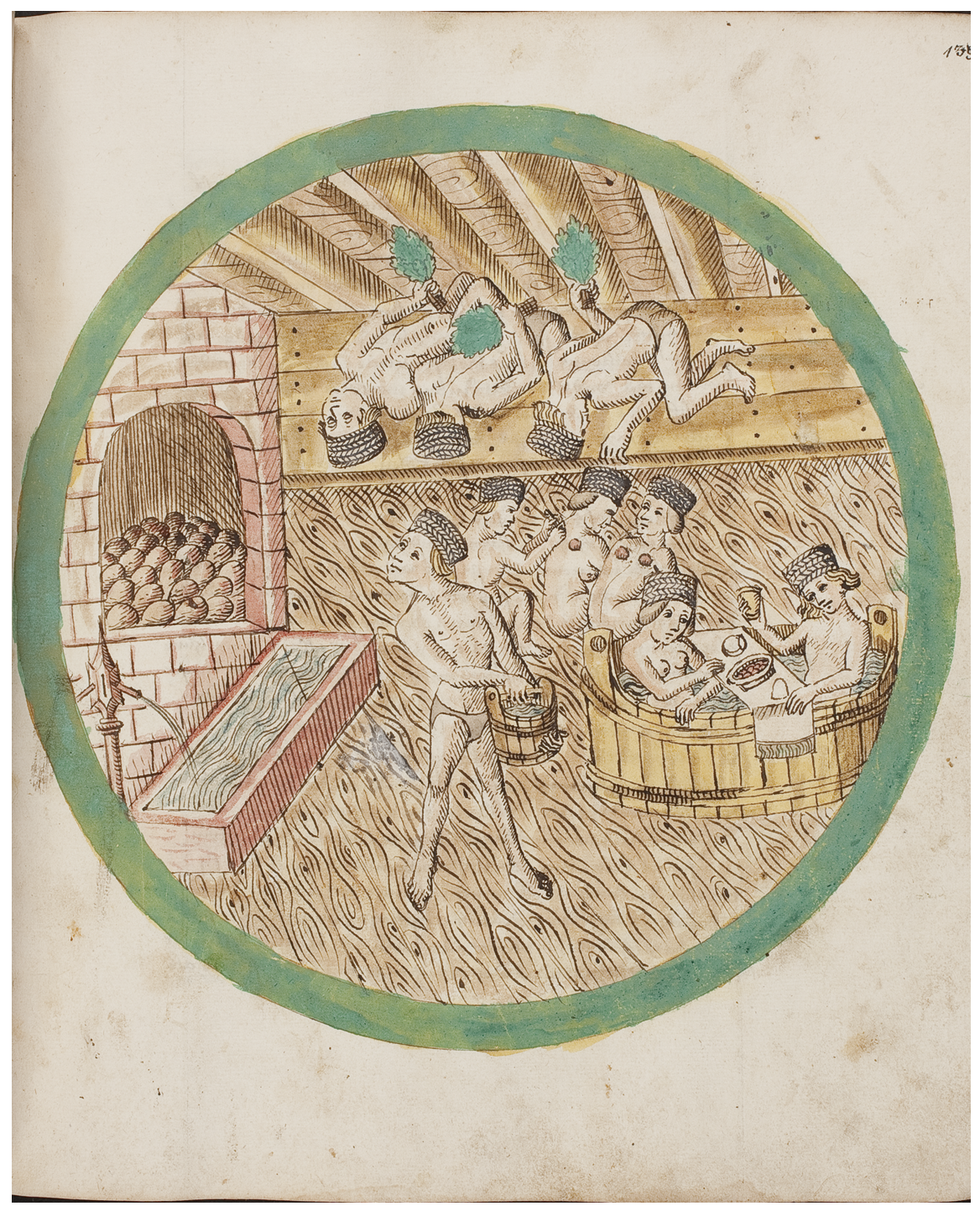

Fig. 16: Bath chamber with clients in a tub, on a sweating bench and undergoing cupping, Herzog August-Bibliothek, Wolfenbüttel, Cod. Guelf. 8.7. Aug. $8^{\circ}$, fol. 139r. 
form fronds or brushes, served to "stroke" the skin and stimulate the flow of sweat. ${ }^{558}$ Bathers could also have their hair washed, and in Padua, Handsch made use of the services of a barber-surgeon who removed his pubic hair and the hair in other places such as his thighs. ${ }^{559}$ Depictions of naked women from this time suggest that the practice of hair removal, which today is often perceived as a new phenomenon, was widespread at the time, ${ }^{560}$ perhaps encouraged by the aforementioned notion that hair came from excremental matter. Contemporary illustrations of people sitting in tubs with a board lying across, eating or holding one another while nearly naked show how bathhouses were also social places and sometimes more than that. ${ }^{561}$

More than taking baths in tubs, what was important for preventive healthcare were the so-called sweat benches. In the larger bathhouses, these wooden benches on which people would lie were arranged in several levels (see Fig. 16). It was hottest on the Oberbank, the upper bench, ${ }^{562}$ below the ceiling, where the hot steam collected which was produced - just as it is today in steam baths or saunas - by pouring water on hot stones. Lying on the sweat benches, customers and patients could take hot steam baths that promised to cleanse the inside of the body of accumulated waste matter through a plentiful flow of sweat. Bathing in tubs, by contrast, was considered potentially dangerous when there was a buildup of impure matter in the body because bathing only mobilized the matter rather than evacuating it. ${ }^{563}$

The most important surgical "intervention" carried out by the bath-masters was prophylactic and therapeutic cupping. Even a high-ranking patient such as the Baroness of Hungerkasten sought out a bathhouse in which she could have cupping glasses applied to her shoulders to fight catarrh and headache by drawing the morbid matter down from the head. ${ }^{564}$ The bath-master's portable lamp, whose small flame was used to heat the cupping glasses before they were applied to the skin, even served as a symbol of the profession. In contemporary depictions, bathmasters can be identified by the lamp and by their scanty clothing, which was owed to the heat in the bathhouse. ${ }^{565}$

558 Wehrli, Bader (1927), p. 9; Flamm, Bader (1996), p. 15; Widmann/Mörgeli, Bader (1998), pp. 68f.

559 Cod. 11006, fol. $187 \mathrm{v}$.

560 Widmann/Mörgeli, Bader (1998), pp. $76 \mathrm{f}$.

561 Ibid., p. 37.

562 Cod. 11210, fol. 62r.

563 Cod. 11183, fol. 399v: "Impura corpora et repleta non balneanda, quia funduntur humores mali”; similarly Cod. 11205, fol. 119r.

564 Cod. 11205, fol. 406v.

565 Widmann/Mörgeli, Bader (1998), p. 87, with an illustration. 
In the Middle Ages, a barber quite often also worked in the bathhouse and was responsible for shaving and cutting hair. Some bath-masters hung up a barber's bowl of the kind that the customer had to hold under his chin during wet shaving, to advertise the work of the barber at their business. ${ }^{566}$ By the sixteenth century, however, the barbers had become barber-surgeons and as such significant competitors for the bath-masters. Indeed they had largely - with the exception of cupping - displaced them from the curative arts in a narrow sense. ${ }^{567}$ Tellingly, Handsch spoke much more frequently of barbers ("barbitonsores") than of bath-masters ("balneatores") in the context of patient treatment. Alongside hair cutting and beard trimming, the domain of the barbers was predominantly considered to comprise minor surgery, pulling teeth, and the treatment of wounds and injuries as well as external diseases such as ulcers and other pathological skin changes with ointments and compresses. Handsch gave numerous descriptions of such activities performed by barbers, for example stitching a head injury, ${ }^{568}$ setting a dislocated arm, ${ }^{569}$ and cutting open gums and extracting a tooth. ${ }^{570}$ The most important surgical intervention for barber-surgeons was bloodletting, which for many seems to have constituted a central source of income. As a rule, it was to the barber-surgeons that learned physicians sent their patients when bloodletting was indicated. ${ }^{571}$

The barber-surgeons had a great advantage over the bath-masters insofar as they did not require a bathhouse. They could practice in the houses of their customers or patients, which suited affluent patients very well. Unlike the bathmasters, they furthermore did not suffer the consequences of the repeated severe shortages of wood. ${ }^{572}$ And they were also not affected in the same way by the population's fear of contracting the new French disease. This fear has often been connected to the loose sexual mores in some bathhouses. But clearly, the crux of the matter was something else: given the disease concepts described above, there was a significant concern that the disease could be transmitted by the vapors that emanated from the skin, especially from profusely sweating people affected with the disease. ${ }^{573}$

566 Ibid., p. 79, with an illustration.

567 For surveys see Wehrli, Bader (1927), pp. 47-77; Flamm, Bader (1996), pp. 22-24.

568 Cod. 11183, fol. $164 \mathrm{v}$.

569 Ibid., fol. 206r, "barbitonsor rectificavit brachium luxatum".

570 Cod. 11205, fol. 291v.

571 E.g. ibid., fol. $4 \mathrm{v}$.

572 Wehrli, Bader (1927), pp. 32-34.

573 Widmann/Mörgeli, Bader (1998), pp. 158f. 
Although the treatment of external conditions was considered their domain, in practice bath-masters and barber-surgeons often also administered medicines for internal use to their patients and ultimately practiced the full range of the healing arts. In many places, they were not forbidden from doing so. While the surgical activities of the barber-surgeons were protected by guild laws and other regulations, the internal treatment of illnesses - the domain of the physicians often was not, in marked contrast to later times. It was only in a few places, like in Zurich in 1553, that barber-surgeons were outright forbidden from practicing internal medicine as early as the sixteenth century. ${ }^{574}$ In rural areas, where the next learned physician could be quite some distance away, the bath-masters and barber-surgeons, along with lay healers, often provided the first line of treatment for any sort of ailment.

The practice of internal medicine on the part of the bath-masters and barber-surgeons was a thorn in physicians' sides. Some physicians picked their craftsmen competitors to pieces. In this regard, leading proponents of academic medicine were for once in agreement with Paracelsus, who polemicized against the bath-masters and feldshers who - he claimed - conducted themselves as surgeons, even "masters", despite lacking the necessary knowledge. ${ }^{575}$ Johannes Lange found very similar words when lambasting the barber-surgeons of his time, writing that with no anatomical knowledge whatsoever and after having no more than seen a butcher slaughter a calf or a piglet, they were ready to abuse their patients with a knife and hot iron. ${ }^{576}$

In everyday practice, as Handsch's notes show, physicians and bath-masters and barber-surgeons often got along with one another and coexisted quite peacefully. ${ }^{577}$ Many patients who were being treated by physicians for an internal disease such as the French disease also developed ulcers or abscesses or other skin changes which, because they were external complaints, fell in the domain of the bath-masters and barber-surgeons. And as we have seen, physicians for their part were sometimes asked for their advice about wounds and operable complaints such as bladder stones and hernias. Even in published case histories penned by physicians, there are numerous indications that learned physicians cooperated with barber-surgeons, indeed that they even treated patients together. ${ }^{578}$ What is more, it was apparent to physicians - as Handsch's notes vividly show - that

574 Wehrli, Bader (1927), pp. 62f.

575 Paracelsus, Grosse Wundartzney (1536), conclusion (“Beschlußred”, no pagination).

576 Lange, Medicinalium epistolarum (1554), p. 13.

577 Thus also Schlegelmilch, Blick (2019), pp. 75-76.

578 E.g. Cod. 11207, fol. 161r, on a severly injured man whom Mattioli treated "together with the barber-surgeons" ("cum barbitonsoribus"). 
they stood to learn something from barber-surgeons. Learned physicians actually had great respect for the knowledge and skills of established, experienced surgeons such as the court surgeon Hildebrand who practiced in Handsch's immediate environment. It was with good reason that Handsch made detailed notes of Hildebrand's methods for various surgical interventions. ${ }^{579}$ Occasionally, Handsch even deferred to Hildebrand's opinion when it came to the treatment of internal diseases. When Handsch wanted to bleed a fever patient, for example, he ultimately did not do it because Hildebrand did not consider it necessary for a simple tertian fever. ${ }^{580}$ Surgery, as a matter of fact, serves as a prime example of that close and mutually productive relationship between book-learning and craftsmanship in the early modern period, which Pamela Long and Pamela Smith underscored in their studies about other fields of knowledge and activity. ${ }^{581}$

\section{Lay Healers}

In their censure of the numerous lay healers, who treated patients in towns and in the countryside without formal education and without the permission of the authorities, medical authors were even more relentless. In printed works and in their petitions to the authorities, they condemned the "fraud" and the "murderous acts"582 of these "bunglers". They warned of the great harm "people's best and most beloved treasure, namely life and health", ${ }^{53}$ suffered through their doings. Sometimes they even named specific healers, demanding that an end be put to their "dirty tricks". 584

It was with good reason that such polemics were chiefly written in the vernacular. The authors were seeking not only to warn sick people about the "fraudulent machinations" and the "dangerous ignorance" of the lay healers. A second and

579 See the chapter on surgery in Part II.

580 Cod. 11183, fol. 449v.

581 Long, Artisan/practitioners (2001); Smith, Body (2004).

582 As indicated already by the title in Horer, Artzney-Teuffel (1634).

583 Preface of the German translator of Foreest, Uromanteia (1620), p. 8; similarly, dedicatory epistle by Johannes Crato to Da Monte, Consultationum centuria secunda (1559); the critics frequently combined their attacks with a fundamental rejection of the diagnosis of diseases just from the the patient's urine, which many of these empirics (but also many physicians) practiced; examples are Clauser, Betrachtung ([1543]), Hornung, De uroscopia (1611) and, based on Foreest's diatribe, Hart, Arraignment (1623); on the context, see Barbara Elkeles, Medicus und Medikaster (1987); Stolberg, Harnschau (2009), pp. 187-195.

584 See e.g. the supplication by Jeremias Martius and other Augsburg physicians, $16 \mathrm{Au}$ gust 1573 (www.aerztebriefe.de/id/00002330, S. Herde). 
decisive target audience was the authorities, who would have actually constituted the main readership considering the limited literacy of most of the population. It was the authorities who, through their "unobservant supervision" allowed "any fellow who comes along to go about his mischief and sinful murder". ${ }^{585}$ To "put things right”, the physicians demanded severe punishment for lay healers. Cordus, for example, lamented that forgers, who only conned people out of their money, were burnt at the stake, while those who robbed people of their lives were allowed to run free. ${ }^{586}$ Sounding the same alarm bells, Ananius Horer wrote that anyone passing himself off as a baron would be punished, but not the person who pretended to be a physician. ${ }^{587}$

Already as students, budding physicians were initiated into the struggle against this opponent. An incident in Montpellier, reported by Felix Platter, is telling. An empiricus who was caught with medicinal ointments and powders was apprehended and led through the town by students. As punishment, he was forced to sit backwards on a donkey while those surrounding him scorched his face, hands, legs, and clothes with burning branches. ${ }^{588}$ Under headings such as "Contra empiricos", quite a few entries in Handsch's notebooks show that he, too, had to some extent adopted the negative image that was being presented of lay healers in polemical treatises and petitions. We read, for example, "They want to be physicians, just as peasants want to be nobility", ${ }^{589}$ or, "They practice medicine at random", or, as he added in Latin, "An incomplete physician is a complete murderer". 590

For a long time, historians stood in the same camp as the learned physicians, bemoaning the "dreadfulness" of the "quacks" and "charlatans" who stood in the way of true - that is learned - medicine. However, if, for a moment, we consider this through the lens of modern medicine, it is by no means a given that the therapeutic outcomes of the empirici were inferior to those of learned physicians. Quite the contrary, from a modern perspective, administering a simple laxative or treating a disease with magical, sympathetic rituals would in most cases have been more salubrious than the extreme and likely damaging again, from today's perspective - treatment that physicians sometimes gave their patients: drastic purgatives, numerous other medications, bloodletting, enemas, and further procedures. Renaissance physicians may have indeed been

585 Preface of the German translator of Foreest, Uromanteia (1620), p. 8.

586 Cordus, De urinis (1543), no pagination.

587 Horer, Artzney-Teuffel (1634), p. 29.

588 Germain, Les étudiants (1876), p. 38.

589 Cod. 11206, fol. 97r.

590 Ibid. 
convinced of the dangers they were depicting so vividly and harrowingly. From a modern perspective, however, the struggle against the empirici was unmistakably also a central element of a more comprehensive professionalization and monopolization campaign that unfolded over the course of centuries. ${ }^{591}$

To do justice to the activities and the significance of lay healers, it is necessary to distinguish two groups. There were, first of all, those itinerant healers and vendors of medicine who advertised their services and remedies on market squares; Handsch saw them in Venice. ${ }^{592}$ And then there were the sedentary lay healers. The distrust of the itinerant healers and vendors of medicine whom the physicians called circumforanei or circulatori, makes some sense, also in historical retrospect. By the time it was possible to determine whether their remedies were effective and their treatment successful or not and whether they were perhaps even cunning crooks, these itinerant healers were often long gone and could no longer be made accountable and punished. Vagrants usually sat on a horse so that they could flee, as Handsch put it laconically. ${ }^{593} \mathrm{He}$ also retold a story that offered evidence of their deceptive machinations: an acquaintance of his allegedly saw with his own eyes how one such itinerant healer drank from wine that had a living snake in it. Afterwards, the man's abdomen swelled up and he measured his girth with a rope. Then he drank the theriac which he was touting. His abdomen shrank back down, thus supposedly proving the effect of the theriac. Handsch, however, considered it impossible that the snake's poison would only cause the belly to swell without also severely affecting the heart and liver, and without causing the man to faint. ${ }^{594}$ In some places, the municipal authorities had taken action against such itinerant healers and drug peddlers as early as the late Middle Ages insofar as they had demanded licenses or even required them to pass an examination conducted by the town physician. In larger municipalities, the medical faculties and the collegia medica gradually acquired the right to conduct examinations and to supervise medical activities. ${ }^{595}$

The itinerant healers and drug peddlers were colorful figures but they ultimately played a limited role in ordinary health care. By contrast, the sedentary healers - the empirici, vetulae ("old women"), 596 or the "Kuedocter" ("cow

591 See also Lingo, Empirics (1986).

592 Cod. 11240, fol. 36r and fol. 37v.

593 Cod. 11205, fol. 205r.

594 Ibid., fol. 134v; in another entry, Handsch bluntly referred to the "fraudes theriacantium empiricorum".

595 Sudhoff, Kurpfuscher (1915), with an edition of relevant sources; Wagner, Doctores (2008); Schütte, Medizin (2017), pp. 216-239.

596 Kinzelbach, Heilkundige Frauen (1999). 
doctors"), as Handsch and other contemporary physicians called them ${ }^{597}-$ played a central role in medical care, especially in rural areas where the large majority of the population continued to live. They were known and trusted. In fact, it is often difficult to draw a line between lay healers whose primary occupation consisted of their healing activities and the numerous medical laypeople who occasionally offered medical advice to neighbors and acquaintances. Because they were rooted in the community, these healers could hardly afford to deceive patients openly and deliberately.

When sick, people from all social classes would at least sometimes seek the advice and help of a lay healer. It is therefore not surprising that the physicians' polemics and petitions were rather unsuccessful in their principal aim, namely to move the authorities to enact drastic measures against the lay healers. Princes and others authorities had little reason to deprive their fellow citizens, their own families, and themselves of the possibility of consulting healers who were widely appreciated for their skill and success in treating patients. Handsch's notes are telling in this respect. Again and again, they make it clear that the clientele of lay healers was by no means limited to simple, uneducated people who lacked the financial means to consult a physician. Patients from the highest circles of society - the preferred clientele of the learned physicians - sought their advice. The archducal chamberlain Christoph von Gendorf, for example, did not have his sciatica treated by Andrea Gallo and Ulrich Lehner alone, but also consulted a lay healer, who completed the treatment using a poultice and could take credit for the cure. ${ }^{598}$ When, in 1565, Sigismund von Berka took a fall while inebriated and injured his head and began experiencing symptoms of paralysis, he, too, sought the advice of a lay healer. The Berkas were one of two powerful noble families in Handsch's hometown of Leipa. ${ }^{599}$ Johannes Schentigar told Handsch about a nobleman at the Habsburg court in Prague who first consulted a lay healer when he was suffering from tertian fever before turning to him, Schentigar. ${ }^{600}$ Even famous medical experts like Johann Neefe had to contend with this type of competition. The Baroness of Hungerkasten for example, while she did have herself treated by him, also spent a month with an unnamed lay healer. ${ }^{601}$

597 Cod. 11205, fol. 408r and fol. 413r.

598 Cod. 11240, fol. 35v; also mentioned in Cod. 11210, fol. 61r; on Gendorf see Bůžek, Ferdinand (2009), pp. $55 f$.

599 Schober/Neder, Sechshundertjahrfeier (1929), pp. 2-10.

600 Cod. 11205, fol. 101v.

601 Ibid., fol. 613r. 
Physicians thus had to expect that none of their patients - from simple farmers to even patients from the high nobility - would entrust themselves to their counsel alone, but would also turn to lay healers, sometimes even at the same time. Handsch's notes suggest that some noble patients, like the Berkas, even routinely sought the advice of lay healers, indeed that these lay healers more or less entered their service. There is mention of an "empiricus D[omi]ni Rosensis", of an "empiricus apud Berkam"602 and of a "medicus empiricus" called Bacchus at the court of Emperor Maximilian II. ${ }^{603}$ The latter was said to have diagnosed a "yellow, black, and white jaundice" in a noble female patient and to have treated it with a powder he made from a root which he gathered not far from the Prague castle. ${ }^{604}$

Handsch's father was a member of the town council and his son was a physician but in Handsch's own family, too, a lay healer was consulted regularly. Handsch called him "our empiricus" ("empiricus noster") or the "Leipa empiricus" ("empiricus Lippensis"). Apparently, this was one and the same person, likely a certain Lorenz. ${ }^{605}$ Handsch mentioned him many times in his notes, and both his father and stepmother consulted him. ${ }^{606}$

The empirici were not only serious economic competitors; they also posed a threat to the status and authority of learned physicians and academic medicine. When these healers were able to cure patients, it called into question the superiority of the rational, scholarly medicine that the physicians were so vehemently and categorically defending. It was clear to the physicians that patients were looking for one thing above all else: being cured. And physicians could not deny that in the hands of the empirici, too, numerous patients became well again. Understandably, patients and those around them ascribed their recovery in such cases to the skills and remedies of the lay healer. In the worst case, physicians found themselves publicly exposed and shamed by such curative success. As a student in Padua, Handsch noted down, for example, the story of a man with an incessant nosebleed. The attending physicians were trying everything under the sun, but after twenty days, they declared the case hopeless. At this point, an old woman advised the patient to eat a fresh raw egg, including the shell. He did this, and five days later the nosebleed was gone. ${ }^{607}$ In Prague,

602 Cod. 11251, fol. 116v.

603 Cod. 11183, fol. 154v and fol. 285r.

604 Ibid., fol. 285 r.

605 E.g. Cod. 11205, fol. 116r, fol. 122v, and fol. 124r; Cod. 11183, fol. 142r.

606 It is not known whether there was a learned physician or an apprenticed barber-surgeon or bath-master in Leipa, at the time.

607 Cod. 11251, fol. 31v. 
a man from the court told Handsch about his experience of having been diagnosed as consumptive by physicians, who considered him a desperate case. He was coughing and becoming emaciated. Then an old woman advised him to drink warm beer with a little butter every night when he went to bed. He followed these instructions for several months and recovered. ${ }^{608}$

Stories like these got around. In Trento, Handsch heard about a cardinal who hurt his foot when he fell from a horse in the Holy Land. For years he was treated to no avail by physicians until he finally followed the advice of a countrywoman ("rustica") and successfully cured his affliction with the remedies she recommended. ${ }^{609}$ Another story was about a watchman who cured the Saxon Elector Friedrich of his podagra within a short period of time using a secret remedy. It was claimed the Elector said that if he had known of this remedy and its good effects he could have spared himself all the remedies from the apothecary's shop. ${ }^{610}$ According to another of Handsch's entries, a vetula was said to have laughed at the medical doctors ("medicos doctores") because they were unable to gain the upper hand on a patient's bladder stone. She gave him a simple remedy made with the dried stems of beans and peas as well as bean flour in mutton broth and in this way cured the patient without any further medicine. ${ }^{611}$ And in Italy, a vetula made a "scandal" out of the physicians ("ad scandalum posuit") by successfully treating the lame and gouty with a simple remedy of cloves, sage, saffron, and cream. Handsch clearly believed in the effects: he recorded the remedy in his Liber experimentorum, his collection of tried and tested medicines. ${ }^{612}$ Handsch himself, too, suffered such humiliations. In the case of a female patient experiencing chronic colics, he ultimately had to admit that the treatment of a female lay healer was more successful than his own. Over the course of months, Handsch had tried numerous remedies, to no avail. Then an old woman cured the patient with a decoction of wild thyme (serpyllum). Handsch noted down that wild thyme was an "excellent remedy for colics". 613

608 Ibid., fol. 116r.

609 Cod. 11251, fol. 7r.

610 Ibid., fol. 33v; presumably, Handsch was referring to Friedrich III (1463-1525).

611 Ibid., fol. $74 \mathrm{r}$.

612 Ibid., fol. 85v.

613 Ibid., fol. 37v, "contra colicam experimentum optimum”. 